\title{
Maintaining Effort and Interest despite Challenges during the COVID-19 Pandemic? A Process Tracing Approach to a Teacher's Grit during an Online L2 Course
}

Majid Elahi Shirvan, University of Bojnord

iD https://orcid.org/0000-0003-3363-8273

elahishmajid@gmail.com; m.elahi@ub.ac.ir

Mojdeh Shahnama, Ferdowsi University of Mashhad

iD https://orcid.org/0000-0002-8679-0642

mojdeh.shahnama@gmail.com

\author{
Nigel Mantou Lou, University of Victoria \\ (iD https://orcid.org/0000-0003-1363-833X \\ nigellou@uvic.ca
}

Elham Yazdanmehr, Attar Institute of Higher

Education

iD https://orcid.org/0000-0002-9414-7251

yazdanmehr@attar.ac.ir

\begin{abstract}
Grit-the ability to maintain effort and interest for long-term goals-is argued to be an important individual factor for achievement, especially in the face of obstacles. However, little research has examined the possible fluctuations of effort and interest and how challenges may trigger the changes of effort and interest. In this study, we measured a teacher's grit at the beginning of an online course during the COVID-19 pandemic, and we focused on the changes in a teacher's effort and interest throughout the course. In this case study, we unpacked the explanations of possible changes in grit via process tracing. Despite the fact that the teacher scored high on the grit scale, we found that the sudden shift from in-person to online teaching had put much pressure and demand on the teacher. The new teaching challenge influenced the teacher's self-evaluation of her teaching performance and students' engagement, which led to changes in effort and interest. Therefore, we argue that one's average grit (e.g., measured by grit scale) cannot be the representation of their ability to maintain interest and effort on different occasions due to the influence of different situational causes or pressure. Specifically, during the course, the teacher's effort and interest underwent changes on four occasions, characterized by four distinct dynamic patterns in terms of the interaction of high and low interest and effort. The four emerging patterns of $L 2$ teacher effort and interest indicate that the construct of grit could be explained in terms of four dynamic clusters or archetypes. This study provides implications for understanding the complex dynamic nature of grit, which can be further explored through cluster analytic approaches in future studies.
\end{abstract}

Keywords: L2 teacher, grit, effort, interest, COVID-19 


\section{INTRODUCTION}

Online learning, which played a complementary role in traditional mainstream education in the pre-COVID-19 era, has dominated global education during the pandemic (Tesar, 2020). The new conditions seem to be unprecedentedly challenging to teachers and learners (MacIntyre et al., 2020; Peters et al., 2020) and influence their psychological traits, including problems caused by the emergency conversion to online language teaching (MacIntyre et al. 2020). Many language teachers are now supposed to deliver major workloads online, but they might not have been prepared for such a sudden online delivery as they might hardly strike a balance between personal and professional chores. On the other hand, language teachers, their students, and language school directors and supervisors need to cope with the demands of the sudden online education brought on by the pandemic crisis as language schools are closed. Thus, the COVID-19 pandemic crisis might underpin the emergence of different patterns of effort and interest of language teachers. Such challenges for language teachers can be addressed by the positive psychology line of research, which has been flowering in the field of second language acquisition (SLA; see Dewaele et al. 2019).

Research on positive psychology provides insights into understanding how people respond and cope with new challenges (Gable \& Haidt, 2005; Seligman, 2002). One positive psychology factor that has received increased attention recently is grit. Grit is defined as "the perseverance and passion for long term goals" (Duckworth et al., 2007, p. 1087) and has two dimensions, perseverance of effort (PE) and consistency of interest (CI), with the emphasis on its stability. Duckworth et al. (2007) argued that grit is an important individual factor for achieving difficult goals. Duckworth (2013) further argued that grit is even a better predictor of success than cognitive ability.

Grit has recently drawn the attention of researchers in the field of SLA. Although the work of grit is promising, the majority of the work in language learning has focused on the learner (cf. Mercer et al., 2016). Relatively little attention has been paid to language teachers (Mercer \& Kostoulas, 2018). In domain-general investigations of teacher's grit, grittier teachers are better adept at improving students' academic performance (Robertson-Kraft \& Duckworth, 2014). Grit as an individual difference (ID) has also been revealed to predict teacher performance prospectively and brought about teacher's higher effectiveness at schools (Duckworth et al., 2007; Duckworth et al., 2009). Revisiting IDs in SLA, Dörnyei and Ryan (2015) raised serious issues concerning the classic assumptions of IDs, one of which is that (b) "IDs are relatively stable." They pointed out that "when we look more closely, individual learner characteristics are not stable but show salient temporal variation...." (p. 6). Consistent with the "dynamic turn" in SLA (see de Bot et al., 2007), Dörnyei and Ryan (2015) further noted:

IDs are better seen as ongoing, evolving constructs rather than stable learner traits. Arguably the most significant contribution of a complex dynamic systems approach is in its role as an overriding guiding principle that positions change rather than stability as the norm, moving us away from static conceptualizations of learners toward embracing notions of change and growth (p. 6).

IDs, from the complex dynamic systems theory (CDST) viewpoint, are dynamic and self-organize or emerge into different patterns under the influence of the interplay between various situated factors (Hiver \& Al-Hoorie, 2020; Hiver et al., 2021; Larsen-Freeman, 2020). Consistent with the shift from a stable view to a dynamic one towards IDs in SLA, concerning the construct of grit, Credé (2018) maintained that the construct should no longer be seen as either high-or-low but from a dynamic perspective. Furthermore, examining L2 grit from a longitudinal perspective, Alamer (2021) reported that later achievement of vocabulary learning could not be explained by the initial states of grit but by the growth of grit over time, implying the temporal change of L2 grit. Such points emphasize the need to go beyond conventional methods of analyzing an ID, such as L2 grit, with a longitudinal nature. With these explanations in mind, in this study, we explore how an L2 teacher's effort and interest emerge in the reality of online teaching during COVID-19 through a longitudinal approach. In the following sections, we review research on grit and domain-specific grit in SLA. It will show the existing gap in the literature for a dynamic approach using qualitative tracing of the trait in teaching an online course. 


\section{LITERATURE REVIEW}

\section{Grit}

Grit is defined as "the perseverance and passion for long term goals" (Duckworth et al., 2007, p. 1087) and has two dimensions, perseverance of effort (PE) and consistency of interest (CI). Grit is argued to be particularly valuable in conditions marked by high levels of adversity, ambiguity, and complexity (see the introduction of the special issue for a discussion; Khajavy et al., 2020). For example, research showed that gritty students put more effort and tried harder when experiencing difficulties (Lucas et al., 2015; Silvia et al., 2013).

Grit has been mainly studied from a stable trait-like perspective, which has led to a bulk of studies that examined the role of grit in academic achievement (see Credé et al., 2017). However, research on grit has received some criticism over the past several years, including its construct validity. As Credé (2018) argued, the operationalization of the construct has led to a misinterpretation that grit should be defined in terms of high perseverance of effort and high consistency of interest, such that any low levels of each of these two sub-constructs (e.g., high perseverance and low interest) should not be regarded as grit. This criticism is consistent with Lowie and Verspoor's (2019) argument that learners are not ergodic ensembles. That is, one's average trait cannot be the representation of one's behavior on different occasions due to the influence of situational causes or pressure. This means that assuming individuals simply acting in a constant manner on all occasions is misleading, and their behavior should be taken from a dynamic perspective. Therefore, studying one's trait grit may not reflect their interest and effort across different situations. However, little research has explored the changes in grit.

\section{Domain-Specific Grit}

In the SLA domain, grit has been largely under-researched, and the earliest study was conducted by Lake (2013), who used the general grit scale by Duckworth et al. (2007), and found that grittier students have a stronger interest in spending time and putting efforts in L2 learning. Also, Changlek and Palanukulwong (2015) explored gritty students' motivational characteristics and found that high achievers were grittier. They also found that grit is positively correlated with students' motivation and negatively with anxiety.

Using a modified version of the general grit scale, Kramer et al. (2017) tested the predictive validity of grit in a sample of foreign language learners in Japan. They found a moderate association between L2 learners' vocabulary achievement and grit. Robins (2019) explored the effect of grit on retention and academic success of online English as a second language (ESL) learners in the US. The findings showed that the overall grit score was not a significant predictor of retention. Yet, it was weakly correlated with L2 learners' average score (GPA). Wei et al. (2019) found a positive but low correlation between grit and English language scores of secondary school students in China. Yamashita (2018) estimated no correlation between Japanese learners' grit and GPA. More recently, Khajavy et al. (2020) explored the association between grit and language mindsets, the beliefs about whether language learning ability is fixed or malleable (cf. Lou \& Noels, 2019). They found that grit was weakly associated with language mindsets but not with L2 achievement.

It is noteworthy that the inconclusive results of these studies implied the need for an L2-specific grit scale for a more accurate measurement of the construct in SLA (Sudina et al., 2020). Outside SLA, the domain-general SLA has been criticized in favor of the domain-specific conceptualization of grit (see Clark \& Malecki, 2019; Cormier et al., 2019; Schmidt et al., 2017). Within SLA, Teimouri et al. (2020) developed the L2-grit scale to measure the domain-specific grit in SLA and argued that such a measure would enhance the validity of grit in SLA. Also, Sudina et al. (2020) investigated the factor structure of this scale and showed that the L2-grit scale yielded sufficient internal consistency and a higher predictive validity than the domain-general scale. Although the introduction of the L2 grit scale paved the way for domainspecific studies of the construct (see Khajavy et al., 2020), the body of research in SLA is still lagging behind the dynamic sphere.

\section{Teacher's Grit}

Besides learner's grit, recent attention has been drawn to teacher's grit in both domain-general and specific spheres. Teacher's grit was revealed to affect student grit in 
educational studies (McCain, 2017). An L2 teacher's grit was hypothesized to be associated with a growth mindset, perseverance and well-being (Zeng et al., 2019). Teachers capable of maintaining a passion for work and tackling occasional challenges, and not getting disappointed midway showed the perseverance of efforts at the core of Duckworth et al.'s (2007) definition of grit. A recent study on L2 teacher's grit has shown that many factors can affect teacher's perseverance and passion (Sudina et al., 2020). These factors include job insecurity, low wages, cultural differences, linguistic challenges, teacher's confidence, and increased workload (Sudina et al., 2020).

\section{The Current Context}

The pandemic has placed L2 teachers under more pressure than before because they are supposed to cope with unpredictable challenges and difficulties, which might position them in situations characterized as fighting a losing-battle. According to Allen et al. (2020), during the crisis of COVID-19, teachers are experiencing much uncertainty in their profession. They noted that the rapid shift to online modes of instruction has resulted in intensified workloads because teachers are supposed to engage their learners and become skillful in selecting and using the required software programs.

Also, in their exploration of three EFL teachers' perceptions of online teaching during the COVID-19 pandemic in the context of China, Gao and Zhang (2020) reported that none of the teachers were certain about the effectiveness of online instructions. Teachers were experiencing anxiety, worry, confusion, and psychological pressure in their preparation for online language teaching. They attributed these issues mainly to their lack of literacy in information technology and inadequate conditions for language teaching.

The pressure language teachers experience during this crisis is also reflected in the distinction between distance education in response to COVID-19 and conventional distance education (Al Lily et al., 2020), as the implementation of the latter is forceful, sudden, and unready. One of the factors contributing to teachers' pressure during this critical time can be the intensification of efforts by stake holders to benefit from the over-demand for distance education. Müller and Goldenberg (2020) have described this pressure as traumatic stress from work. Given the new teaching challenges, it may be difficult for teachers, even those who scored high on the L2-teacher grit scale, to maintain high interest and effort throughout different occasions of an online language course during the pandemic.

In this study, we argue that one's average grit cannot be the representation of their interest and effort on different occasions due to the influence of different situational causes or pressure. Thus, a teacher's emergence of grit needs to be explored in the complexity of emergent situations (Credé, 2018; Maddi et al., 2012).

On the other hand, from a methodological perspective, in the literature, there is a wide gap and absence of longitudinal idiographic research, which best suits the dynamic features of personality traits (Beck \& Jackson, 2020) to locate the variable of interest in dynamic association with other variables present in the immediate environment (Hiver \& Al-Hoorie, 2020). To fill these gaps, the present research firstly narrowed down its focus on the under-researched subject of L2 teacher's grit. Secondly, it focused on L2 teacher's grit in the present conditions of crisis distance education, globally prevalent at a rate never experienced before. Thirdly, this research was idiographic in type and, more specifically, a case-centric process tracing, which is an innovative methodology in complexity research in SLA (Hiver \& Al-Hoorie, 2020). This method is best fitted to trace the steps of a phenomenon, unravel the mechanisms of the variable of interest, its dynamic manifestations and emergent outcomes (Mahoney, 2012, 2015). Accordingly, the following research question was addressed:

RQ: What can the study of processes and sequences of events in an L2 online course during the COVID19 pandemic reveal about the teacher's emergent patterns of grit in terms of effort and interest?

\section{METHOD}

\section{Design}

The present research was a case study of an L2 teacher. The case-centric and longitudinal nature of this research are justified by the ergodicity issue, which is embraced in complex dynamic systems theory (CDST) that 
acknowledges individual differences, emergent behaviors and contextual sensitivity of human behavior (Lowie $\&$ Verspoor, 2019). The present case-centric study lies within a process-tracing approach (Bennett \& George, 1997). It involves principled procedures for data collection and analysis. This within-case method (a particular form of case study) is designed to analyze complex mechanisms at a micro-level of granularity (Checkel, 2006). The aim is to make inferences about explanations of a case, its dynamic behavior and emergent outcomes (Mahoney, 2012, 2015). The specific outcome in the present study was an EFL teacher's grit in an emergent online course during the COVID-19 pandemic. Process tracing is subsumed under the more inductive types of process tracing, as categorized by Trampusch and Palier (2016). Almost all inductive types of process tracing view time as a key factor in the explanation of an event. And, they mostly rely on alternative explanations to account for the temporally stepby-step unraveled process of an event (Trampusch \& Palier, 2016).

\section{Participant and Setting}

The participant was a 42-year-old female teacher. She held a bachelor's degree in Translation Studies and had 17 years of experience teaching English in traditional face-to-face classes for children, teenagers, and adults. She had four months' experience of blended courses (a mixture of online and face-to-face combined) before the COVID-19 pandemic. The teacher was interviewed during the pandemic while teaching an online course from August $4^{\text {th }}$ to August $20^{\text {th }}, 2020$. Ten students were enrolled in the course taught by the teacher. It was a lower-intermediate level course comprised of nine 75-minute sessions that were set on a different weekday. A traditional grammar-focused method was used by the teacher in the course. The teaching materials were selected based on online sources and were presented as slides and images. The teaching tasks and activities were adapted from the American English coursebook series, Teen2Teen (Saslow \& Ascher, 2014). The final exam was scheduled for the last session in a faceto-face classroom setting. The teacher's performance in the online setting of the course was monitored by the representative of the supervising team of the institute. This representative was present as a member in the online setting.
The online course was held in a private language institute using the Big Blue Button open-source web conferencing system as the platform. In this platform, the teacher could upload any documents and keep everyone in sync with their current page. The system supported voice over IP conferencing. Also, all users could share their webcam while the teacher was sharing her screen. All the students were required to use speakers and microphones to participate.

The teacher was informed at the outset of the purpose of the research, its time requirement, and the data collection procedure. She consented to take part actively and honestly in this case study. The teacher was also ensured of the confidentiality of the information she provided. Her identity was pseudonymized throughout the paper.

The interview was conducted as recorded phone calls in the Persian language-the interviewer's and interviewee's first language. The data were transcribed and then translated into English. The data were analyzed for the content, through which the researchers searched for the patterns of effort and interest, as well as the causes and other variables that showed to relate to the target variables process-tracing.

\section{Instrumentation}

Before the beginning of the course, the teacher responded to the L2 Teacher Grit Scale on a 5-point Likert scale (Sudina et al. 2020). The scale was reported to have an internal consistency of .77 in one previous study (Sudina et al. 2020) and consists of 9 items (e.g., "I am a hardworking ESL/EFL teacher" = effort; "At times, I have lost interest in teaching ESL/EFL" = interest). In this study, the teacher's grit was 4.44, which was higher than the mean score of 3.88 $(S D=.58)$ as the cut-off score of the scale (Sudina et al., 2020). Given this, an interview was also held with the teacher before the beginning of the course to delve more deeply into these two factors based on her previous language teaching experiences.

The data in this case study were collected using a semistructured interview, which delved into the traces of teacher's perseverance of efforts and consistency of interest as experienced in different steps of the online course. The content was developed to meet the requirements of CDST methods as elaborated by Hiver and Al-Hoorie (2020) to 
locate the teacher's effort and interest within a whole complex system of class and the underlying interconnections of contextual features-whatever the teacher herself found relevant and thus, reported. The semistructured format of the interview, along with open-ended questions, aimed to encourage the participant to elaborate more on the relevant points in an exploratory manner (Dörnyei, 2007). The teacher was interviewed after each session of the course to report on her efforts and interest experienced in teaching the course. The interview guide is provided in the Appendix.

\section{Data Collection}

In the present research, fluctuations in grit and its emergent manifestation patterns were traced during an entire course (session by session). In order to adhere to a principled process-tracing approach, the following procedures proposed by Bennett and Checkel (2015) were followed: determining the outcome in question and potential expected mechanisms, choosing a representative case and setting the time when to start evidence collection, taking potential biases into account, considering a range of alternative explanations for mechanisms, following evidence to accept or reject alternatives, eliminating some alternatives gradually, extracting more detailed evidence for the rest of explanations, and finally determining when to stop the process.

The data were collected through an interview, analyzed for content and process-traced session by session to open the black box of the mechanisms involved as an interconnected network of factors underlying the teacher's emergent patterns of grit. As there was no pre-established theory explaining the cause of L2 teacher's grit, the literature was searched for potential factors associated with or predicting grit. Of note is the significantly lacking literature on L2 teacher's grit, which further points to the need for relevant research.

\section{Data Analysis}

We followed the analysis procedure described above. Specifically, we selected a representative participant, who was an experienced EFL teacher and had only a short experience of blended courses before the pandemic. She showed interest in and commitment to this study and provided detailed answers to interview questions. The data collection time and duration were scheduled to correspond to the plan of the target course. The variable of interest was the teacher's grit consisting of her perseverance of efforts and consistency of interest throughout the course. Because having failure is a characterizing condition in grit (Lucas et al., 2015), we focused on the failure or possibility of failure as the occasions for the changes in the teacher's interest and effort during the online course. In other words, we considered the teacher's possibility of failure in her efforts and interest as the criterion reflecting the change in her grit.

\section{RESULTS}

To answer our research question, an overall view of the fluctuations of the teacher's grit throughout the target course - in occasions of pressure, demand, and the possibility of failure - as suggested by Lucas et al. (2015), was taken into consideration. Thus, the teacher's grit expressed in her accounts was traced session by session (see Figure 1). Her efforts and interest were traced not only across sessions but also within them to better reveal the possible variations. The findings of each session analysis of the teacher's efforts and interest showed that a range of alternative explanations could be regarded for the change in the teacher's effort and interest. Moreover, we focus on those explanations that are paired with the evidence of pressure or challenges as they are regarded as the causes of changes in the teacher's grit (Lucas et al., 2015; Silvia et al., 2013). In other words, changes that cannot be explained by the teachers' experiences of pressure or challenges were not further analyzed in this study. For instance, as shown in Figure 1 and Table S1 (see Appendix), in the first session of the course, the teacher's grit underwent change only in the middle of the session, but the teacher did not report any particular pressure or challenges for the changes. Therefore, although there are other explanations for the changes of effort and interest (see Appendix), they are not further considered. In general, during the course, the teacher's interest and effort changed on five occasions, which led to the characterization of the teacher's grit in four distinct dynamic patterns. Below, we discuss each of the patterns. 
Figure 1. The Trajectory of the Intensity of the L2 Teacher's effort and interest in the Online Language Course

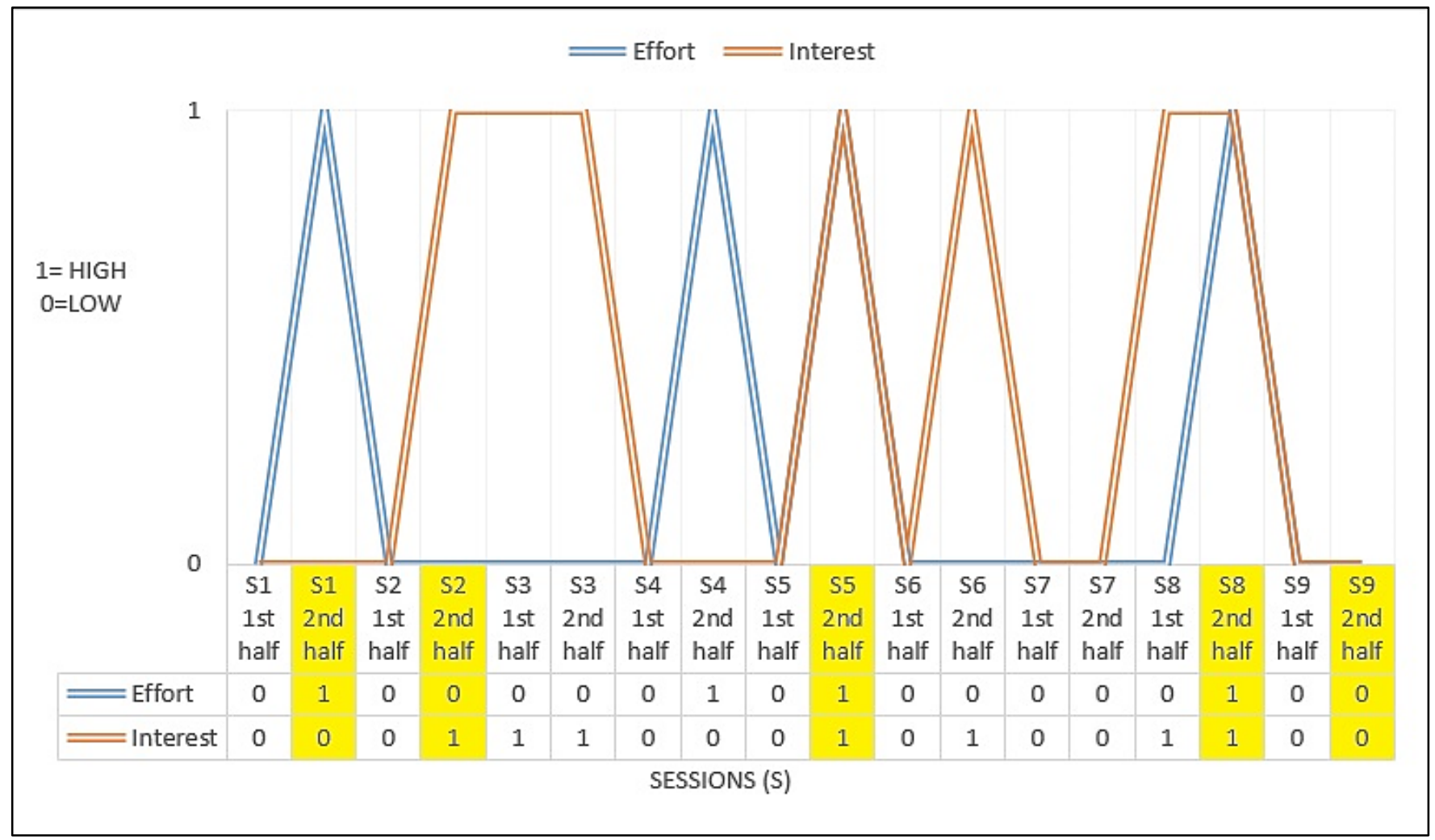

\section{High Effort and Low Interest}

The teacher's grit emerged as high effort and low interest in the first session. The students started doing an in-class exercise (filling out a schedule) regarding time expressions with the present continuous tense. Although she increased her effort to make this exercise easy to understand, the students did not understand the subject matter and were still confused. This sense of confusion among the students also put her under time pressure because much class time was wasted while trying to regain control of the class. Therefore, she had to increase her effort to finish the scheduled lesson plan by the end of that session. She had to follow the teaching schedule due to the fact that the next week the students were supposed to have an exam in which their knowledge of time expressions would also be assessed, and the scores of the students were monitored by the supervision team of the institute. She could not stand her students' missing points despite her effort to emphasize this grammatical point. She noted:
Failure of my students in the exam can also be my failure too. Once I noticed the more efforts, I made to expand my explanations about the timeexpressions, the more confused they became. I think this was mainly due to the online mode of the sessions, but it was tough. Besides, I could not imagine being misjudged by those monitoring my performance and the students' performance in the exam. This horrible image made me increase more effort and never give up, I felt losing my interest in online teaching though.

\section{Low Effort and High Interest}

The teacher's grit emerged as low effort and high interest in the second session. The students were supposed to make sentences using present continuous form while focusing on possessive and objective pronouns. However, after practicing it several times during past semesters, they still 
made obvious mistakes, especially in making questions. It should be mentioned that the previous semester of students was also taught by Maryam. Despite her continuous efforts to help them understand the question format, the students became more confused. Therefore, because this was an important grammar point, she decided to quit the topic and start teaching another point. This was possibly due to the pressure of being under supervision because she felt that the more she tried to manage her students' sense of confusion, the more they were confused. And, she worried that this sense of confusion could be evaluated as a poor performance in the eyes of the supervision team. Thus, she started teaching the reading section instead of changing the atmosphere of the class. She reported:

I'm so obsessed with my students' learning, even in learning the simplest grammatical points. Having spent more time and effort to help them know the use of different functions of present continuous, I was still not satisfied with their performance. While drawing their attention to the question format using possessives and object pronouns, they seemed to be more confused and asked for more help. As I made more examples, the situation went worse, and they appeared deeper in doubt. I was still keen on the topic because I fancy teaching grammar, but I was totally aware of the session being recorded and felt that more efforts might lead to more post-session questions by the students and, consequently, the possibility of the consideration of my efforts as a failure by the supervision team in their reflection on this session of mine. This was so stressful. I decided to stop putting further time on the topic because I didn't like to feel like a loser.

\section{High Effort and High Interest}

The teacher's grit emerged as high effort and high interest in the fifth session. The first session began with teaching a new lesson, which involved teaching the vocabulary (about means of transportation) followed by a reading passage (about different ways of going to school) to be taught through a snapshot listening task. The challenge emerged in the second half of the class time when she wanted to give her students a grammar quiz to check their progress about the important grammatical points taught during previous sessions. She was under lots of pressure for several reasons.
First, since it was her first time developing and executing an online exam, she was both excited and afraid. She was excited because she found it an interesting experience. Also, all the tests she had already developed were paper-based. At the same time, she was afraid of not being able to organize and upload the questions properly.

Meanwhile, she experienced heavy pressure as her students' performance in the exam was traced via the online platform developed for the exam sections. In particular, she felt that any confusion on the part of her students in answering the online quiz might be judged as her failure. However, these thoughts did not make her stop doing her best in the development of the online quiz and providing her students with comprehensible instructions to follow the quiz procedures. She pointed out:

While being interested in doing my best handling the quiz part, I was so stressed that the structure of questions was disrupted and that the students might find it difficult to follow the instructions and to answer questions. On the other hand, students' performance in the exam was possible to be tracked in the online platform; so, I was afraid that any issue in holding the online quiz might be judged in a wrong way, or even my failure in handling the online quiz. But I didn't give up. I knew that with more precision and effort, I could cope with the burden. So, I tried hard, and provided my students with examples so that they could easily follow the instructions and answer the questions. I should also admit that I could not hide my excitement to see the results of my efforts in the organization of the online quiz and my students' responses. This was my first experience making an online quiz, and I was really eager to ace it.

In the eighth session of the course, Maryam's grit emerged as a pattern of high perseverance and high interest in the second half of the eighth session. The class began with checking the homework of the previous session. It was satisfactory because most of the students had learned how to use "do/does" when describing occupations and jobs. For the rest of the session, Maryam was supposed to teach a reading passage about "unusual ways to go to school." She noted that she used different ways to teach the topic; however, the topic seemed too challenging for the students. Being aware of the session being recorded, she asked the 
students to stop reading the passage, and she shifted to another task to make them learn the basic words in the text before reading the passage. She pointed out:

It seemed that the students have problems learning the required skills to read the passage. They had the same problems in the previous sessions, but I was obsessed with their reading skills and vocabulary knowledge. In this session, the topic seemed more challenging for them to comprehend. They were supposed to learn some words as the basic words required for the understanding of the passage. However, my presentation of these words and my explanations about them seemed inadequate for them to understand, which I think was due to the online nature of the class. But I really didn't like to feel weak in this experience of online teaching. I know that with more patience and persistence, I can change the situation for my learners. Besides, I was always keen on teaching vocabulary and reading skills. So, to keep my focus on this interest of mine, before asking them to get back to the reading passage, I decided to put time on the pre-reading phase to make sure they would learn these words in depth.

\section{Low Effort and Low Interest}

The teacher's grit emerged as low effort and low interest in the second half of the ninth session. Having checked the students' assignments of the previous sessions in the first half of the session, Maryam started explaining a grammatical feature. The grammar focus was on the difference between the functions of the simple present and the present continuous. Despite her efforts to help them notice this difference, they could hardly see the difference between these time expressions. The teacher had already explained these two tenses a lot throughout the semester. Having seen that the students still had problems with this grammar, she felt she had failed to help students understand the subject matter. Therefore, she did not persist in elaborating on this grammatical point. She also felt disappointed and disengaged in providing the students with further explanations. She explained:

Despite all my previous efforts to help the students learn the different functions of the two senses in previous sessions of the course, I felt that once again, my efforts led to further confusion for my students. I thought that due to the online mode of the course, they were not as responsive or committed as the time they learned English in faceto-face classes. I really had done my best but I was really stressed and frustrated and preferred to quit further explanations about this point. Also, I think I'm no longer fond of teaching these points online; it is painful to see that the supervision team might somehow blame me for the possible poor performance of some of my students in the spoken and written exams, but I think we should postpone such efforts to next semesters when the conditions for holding in-person classes are possible.

\section{DISCUSSION}

\section{The Construct of Grit}

The findings indicated that patterns of the L2-teacher grit in terms of her effort and interest were not consistent with her high grit score measured by the L2 teacher grit scale (Sudina et al., 2020) at the beginning of the course, as her grit emerged in four patterns including both high and low levels of effort and interest. In other words, a teacher's high level, based on the L2 teacher grit scale, does not mean that the teachers would constantly maintain high effort and high interest throughout a difficult time. Given the controversies around the construct validity of grit, this finding can point to different conceptual implications, which are discussed below.

First, these findings provide evidence that studying the construct of grit can provide us with deeper insights regarding the perseverance and interest of an L2 teacher during a language course. In line with the concept of CDST, the teacher's grit as measured by the L2 teacher grit scale could not explain the teacher's grit during the course. This might be due to the emergent pressure for the teacher due to the nature of the environment of the classroom (i.e., online), which could not be considered by the few items of the scale. Thus, as Credé (2018) maintained, one issue of the validity of grit is related to the items of these scales. That is, the items of these scales (e.g., L2 teacher scale) cannot incorporate the totality of the situational conditions and 
pressures that contribute to the emergence of effort and interest.

Second, this inconsistency between the measurement of the teacher's grit and her emergent patterns of grit during an L2 course indicates that the "either-or approach" to the concept of grit, and here more specifically L2 teacher grit, cannot be a reasonable conceptualization of the construct. Instead of regarding the teacher as gritty or not gritty, we noticed that a teacher's grit during the same L2 course could be described in terms of grit degrees.

Third, the remaining controversy of whether grit should be regarded as a composite construct or a combination of effort and interest, or just limited to effort, can be somehow dealt with by the findings of this study. Our findings indicated four patterns of L2 teacher grit under different factors of pressure in the online language course. These patterns of L2 teacher grit might indicate that the construct can be explained in terms of four clusters or archetypes, which can be further explored through retrodictive qualitative modeling, self-organizing maps, or, as suggested by Credé (2018), cluster analytic approaches.

\section{Changes of Grit}

In terms of the mechanisms underpinning the teacher's grit, the findings indicated that the sudden shift from in-person classes to online classes during the COVID-19 pandemic led to the emergence of four patterns of grit, while putting much pressure and demand on the teacher. In this online environment, one of the main determining causes of change in her grit was the monitoring of her teaching performance and her student's performance by the supervision team. The online platforms for teaching language made it easier for the supervision team to track both the students' performance and the teacher's effectiveness. This has possibly put more demands on the teacher to face more success-or-failure situations in her current teaching career. The concern of being misjudged or misinterpreted by the supervision team played an encouraging role in strengthening the teacher's beliefs in her teaching ability and putting more time and effort into overcoming her teaching weakness. On the other hand, the same concern made her consider not teaching online ever. This force also underpinned the consistency of her interest in teaching online along with the changes in her perseverance. At times, while seeing her students' confusion, she was very eager to put more time into clarifying the confusing point for them. However, in some situations, she turned disappointed and lost her focus despite her ongoing perseverance to solve the issue. At some other times, she lost both her interest and hope not to teach online anymore.

In terms of the psychological attributes associated with the teacher's grit, in line with the findings of Lee (2017), stress was a salient factor influencing the change of the teacher's grit. As expected, the emergence of this stress was entangled with the pressure she experienced due to the sudden and forceful implementation of distance education, previously addressed by Al Lily et al. (2020).

\section{CONCLUSION}

This study explored the temporal explanations of L2 grit in an online course during the COVID-19 pandemic. The findings provide evidence that grit should not be limited to the persistence of high-effort-high-interest patterns. We argue that one's average grit (e.g., measured by a grit scale) cannot be the representation of their ability to maintain interest and effort on different occasions. Our findings showed that changes in effort and interest of L2 teacher grit under pressure contribute to the understanding of the dynamicity of grit. From a pedagogical perspective, language teachers should be aware that, under pressure, their perseverance and interest might change, even for a teacher who scored high on the grit scale. Thus, keeping the causes of change of their effort and interest in mind, they can manage to maintain their perseverance and interest at a high level. On the other hand, supervision teams of language institutes should keep in mind that even if teachers have a high level of grit, their interest and effort are susceptible to pressure and failure, which can be intensified by the conditions of the pandemic. Thus, they can take some steps to meet their teachers' concerns and pave the way for their grit to self-organize as a high-perseverance-highinterest state. It should be noted that given the case-centric process-tracing approach used in this study, the findings cannot be generalized to all contexts of language teaching. The emerging four patterns of change identified in this study can be further explored via quantitative methods like cluster analysis or qualitative ones such as retrodictive qualitative modeling. Also, longer time perspectives can be 
considered in the future to explore the emerging patterns of

language teachers' grit.

\section{Author's Contributions}

MS participated in the design of the study, completed the data collection, and was involved in data-analysis and writing of the manuscript. MES, NML, and EY worked on data analysis, and were involved in the writing of the manuscript. MES and NML drafted the manuscript and participated in the interpretation of the results. All authors read and approved the final manuscript.

\section{Ethics Approval \& Consent to Participate}

The participant provided written informed consent prior to enrollment and data collection in the study.

\section{Funding}

The authors received no financial support for this work.

\section{Disclosure Statement}

No conflict of interest was reported by the authors.

\section{REFERENCES}

Allen, J., Rowan, L., \& Singh, P. (2020). Teaching and teacher education in the time of COVID-19. AsiaPacific Journal of Teacher Education, 48(3), 233236.

https://doi.org/10.1080/1359866X.2020.1752051

Al Lily, A. E., Ismail, A. F., Abunasser, F. M., \& Alhajhoj Alqahtani, R. H. (2020). Distance education as a response to pandemics: Coronavirus and Arab culture. Technology Society, 63(1), 1-11. https://doi.org/10.1016/j.techsoc.2020.101317

Alamer, A. (2021). Grit and language learning: Construct validation of L2-grit scale and its relation to later vocabulary knowledge. Educational Psychology, 41(5), 544-562. https://doi.org/10.1080/01443410.2020.1867076

Beck, E. D. \& Jackson, J. (2020). Idiographic traits: a return to Allportian approaches to personality. Current Directions in Psychological Science, 29(3), 301-308. https://doi.org/10.1177/0963721420915860

Bennett, A., \& Checkel, J. (2015). Process tracing: From metaphor to analytic tool. Cambridge University Press.
Bennett, A. \& George, A. L. (1997). Process tracing in case study research. MacArthur Foundation Workshop on Case Study methods. Retrieved from http://www.ciaonet.org/wps/bea03/index.html

Changlek, A., \& Palanukulwong, T. (2015). Motivation and grit: Predictors of language learning achievement. Veridian E-Journal, 8(4), 23-38.

Checkel, J. (2006). Tracing causal mechanisms. International Studies Review, 8(2), 362-370. https://doi.org/10.1111/j.14682486.2006.00598_2.x

Clark, K. N., \& Malecki, C. K. (2019). Academic grit scale: Psychometric properties and associations with achievement and life satisfaction. Journal of School Psychology, 72, 49-66. https://doi:10.1016/j.jsp.2018.12.001

Cormier, D. L., Dunn, J. G. H., \& Causgrove Dunn, J. (2019). Examining the domain specificity of grit. Personality and Individual Differences, 139, 349354. https://doi:10.1016/j.paid.2018.11.026

Credé, M. (2018). What shall we do about grit? A critical review of what we know and what we don't know. Educational Researcher, 47(9), 606-611. https://doi.org/10.3102/0013189X18801322 
Credé, M., Tynan, M. C., \& Harms, P. D. (2017). Much ado about grit: A meta-analytic synthesis of the grit literature. Journal of Personality and Social Psychology, 113(3), 492-511.

https://doi.org/10.1037/pspp0000102

de Bot, K., Lowie, W., \& Verspoor, M. (2007). A dynamic systems theory approach to second language acquisition. Bilingualism: Language and Cognition, 10(1), 7-21. https://doi.org/10.1017/S1366728906002732

Dewaele, J. M., Chen, X., Padilla, A. M., \& Lake, J. (2019). The flowering of positive psychology in foreign language teaching and acquisition research. Frontiers in Psychology, 10, 2128. https://doi.org/10.3389/fpsyg.2019.02128

Dörnyei, Z. (2007). Research methods in applied linguistics: Quantitative, qualitative and mixed methodologies. Oxford University Press.

Dörnyei, Z., \& Ryan, S. (2015). The psychology of the language learner revisited. Routledge

Duckworth, A. L. (April, 2013). The key to success? Grit. [Video]. https://www.ted.com/talks/angela lee_duckworth the key to success grit?language $=$ en\#t-9644

Duckworth, A. L., Peterson, C., Matthews, M. D., \& Kelly, D. R. (2007). Grit: perseverance and passion for long-term goals. Journal of Personality and Social Psychology, 92(6), 10871101. https://doi.org/10.1037/0022$\underline{3514.92 .6 .1087}$

Duckworth A. L, Quinn, P. D., \& Seligman M. E. P. (2009). Positive predictors of teacher effectiveness. Journal of Positive Psychology, 4(6), 540-547. https://doi.org/10.1080/17439760903157232

Dweck, C. S., \& Leggett, E. L. (1988). A social-cognitive approach to motivation and personality. Psychological Review, 95(2), 256-273. https://doi.org/10.1037/0033-295X.95.2.256

Gable, L. G., \& Haidt, J. (2005). What (and why) is positive psychology? Review of General
Psychology, 9(2), 103-110.

https://doi.org/10.1037/1089-2680.9.2.103

Gao, L. X., \& Zhang, L. J. (2020). Teacher learning in difficult times: Examining foreign language teachers' cognitions about online teaching to tide over COVID-19. Frontiers in Psychology, 11, 549653.

https://doi.org/10.3389/fpsyg.2020.549653

Hiver, P., \& Al-Hoorie, A. H. (2020). Research methods for complexity theory in applied linguistics. Multilingual Matters.

Hiver, P., Al-Hoorie, A. H., \& Larsen-Freeman, D. (2021). Toward a transdisciplinary integration of research purposes and methods for complex dynamic systems theory: Beyond the quantitativequalitative divide. International Review of Applied Linguistics in Language Teaching. Advance online publication. https://doi.org/10.1515/iral-2021-0022

Khajavy, G. H., MacIntyre, P. D., \& Hariri, J. (2020). A closer look at grit and language mindset as predictors of foreign language achievement. Studies in Second Language Acquisition, 43(2), 379-402. https://doi:10.1017/S0272263120000480

Kramer, B., McLean, S., \& Martin, E. S. (2017). Student grittiness: A pilot study investigating scholarly persistence in EFL classrooms. Osaka Jokaguin Junior College Kiyo, 47(1), 25-41.

Lake, J. (2013). Positive L2 self: Linking positive psychology with L2 motivation. In T. M. Apple. D. Da Silva, \& T. Fellner (Eds.), Language learning motivation in Japan (pp. 71225). Multilingual Matters.

Larsen-Freeman, D. (2020). Complexity theory. Relational systems in interaction and in interlocutor differences in second language development. In L. Gurzynski-Weiss (Ed.), Cross-theoretical explorations of interlocutors and their individual differences (pp. 189-208). John Benjamins.

Lee, W. W. S. (2017). Relationships among grit, academic performance, perceived academic failure and stress in associate degree students. Journal of 
Adolescence, 60, 148-152.

https://doi.org/10.1016/j.adolescence.2017.08.006

Lou, N .M., \& Noels, K. A. (2019) Language mindsets, meaning-making, and motivation. In M. Lamb, K. Csizér, A. Henry, \& S. Ryan (Eds.), The Palgrave handbook of motivation for language learning. Palgrave Macmillan.

Lowie, W. M., \& Verspoor, M. H. (2019). Individual differences and the ergodicity problem. Language Learning, 69(s1), 184-206.

https://doi.org/10.1111/lang.12324

Lucas, G. M., Gratch, J., Cheng, L., \& Marsella, S. (2015). When the going gets tough: Grit predicts costly perseverance. Journal of Research in Personality, $59,15-22$.

https://doi.org/10.1016/j.jrp.2015.08.004

MacIntyre, P. D. (2017). An overview of language anxiety research and trends in its development. In C. Gkonou, M. Daubney, \& J. M. Dewaele (Eds.), New insights into language anxiety: Theory, research and educational implications (pp. 1130). Multilingual Matters.

MacIntyre, P. D., Gregersen, T., \& Mercer, S. (2020). Language teachers' coping strategies during the Covid-19 conversion to online teaching: Correlations with stress, wellbeing and negative emotions. System, 94, 102352.

https://10.1016/j.system.2020.102352

Maddi, S. R., Matthews, M. D., Kelly, D. R., Villareal, B., \& White, M. (2012). The role of hardiness and grit in predicting performance and retention of USMA cadets. Military Psychology, 24(1), 19-28. https://doi.org/10.1080/08995605.2012.639672

Mahoney, J. (2012). The logic of process tracing tests in the social sciences. Sociological Research Method, 41, 570-597.

https://doi:10.1177/0049124112437709

Mahoney, J. (2015) Process tracing and historical explanation. Security Studies, 24, 200-218. https://doi:10.1080/09636412.2015.1036610

McCain, B. (2017). Effects of teacher grit on student grit and reading achievement: A mixed-methods study
(Publication No. 10269827) [Doctoral dissertation, Indiana University of Pennsylvania]. ProQuest Dissertations and Theses Global.

Mercer, S., \& Kostoulas, A. (Eds.) (2018). Language teacher psychology. Multilingual Matters.

Mercer, S., Oberdorfer, P., \& Saleem, M. (2016). Helping language teachers to thrive: Using positive psychology to promote teachers' professional well-being. In D. Gabryś-Barker \& D. Gałajda (Eds.), Positive psychology perspectives on foreign language learning and teaching (pp. 213229). Springer.

Müller, L. M., \& Goldenberg, G. (2020). Education in times of crisis: The potential implications of school closures for teachers and students. Chartered College of Teaching.

Peters, M. A., Arndt, S., Tesar, M., Jackson, L., Hung, R., Mika, C., Ozolins, J. T., Teschers, C., Orchard, J., Buchanan, R., Madjar, A., Novak, R., Besley, T., Sturm, S., Roberts, P., \& Gibbons, A. (2020). Philosophy of education in a new key. Educational Philosophy and Theory. Advance online publication.

https://doi.org/10.1080/00131857.2020.1759194

Robertson-Kraft, C., \& Duckworth, A. L. (2014). True grit: trait-level perseverance and passion for longterm goals predicts effectiveness and retention among novice teachers. Teachers College Record, 116(3), 1-24.

http://www.tcrecord.org/Content.asp?ContentId=1 $\underline{7352}$.

Robins, S. (2019). Academic achievement and retention among ESL learners: A study of grit in an online context [Unpublished doctoral dissertation]. University of West Georgia.

Saslow, J., \& Ascher, A. (2014). Teen2Teen two: Student book and workbook 2. Oxford University Press.

Schmidt, F. T. C., Fleckenstein, J., Retelsdorf, J., EskreisWinkler, L., \&Möller, J. (2017). Measuring Grit: A German validation and a domain-specific approach to grit. European Journal of Psychological Assessment, 35(3), 436-447. https://doi.org/10.1027/1015-5759/a000407 
Seligman, M. E. P. (2002). Positive psychology, positive prevention, and positive therapy. In C. R. Snyder \& S. J. Lopez (Eds.), Handbook of positive psychology (pp. 3-9). Oxford University Press.

Silvia, P. J., Eddington, K. M., Beaty, R. E., Nusbaum, E. C., \& Kwapil, T. R. (2013). Gritty people try harder: Grit and effort-related cardiac autonomic activity during an active coping challenge. International Journal of Psychophysiology, 88(2), 200-205. https://doi.org/10.1016/j.ijpsycho.2013.04.007

Sudina, E., Vernon, T., Foster, H., DelVillano, H., Hernandez, S., Beck, D., \& Plonsky, L. (2020). Development and initial validation of the L2teacher grit scale. TESOL Quarterly, 55(1), 156184. https://doi/epdf/10.1002/tesq.581

Teimouri, Y., Plonsky, L., \& Tabandeh, F. (2020). L2 Grit: Passion and perseverance for second language learning. Language Teaching Research. Advance online publication.

https://doi.org/10.1177/1362168820921895

Tesar, M. (2020). Towards a post-COVID-19 new normality? Physical and social distancing, the move to online and higher education. Policy Futures in Education, 18(5), 556-559. https://doi.org/10.1177/1478210320935671

Trampusch, C., \& Palier, B. (2016). Between X and Y: how process tracing contributes to opening the black box of causality. New Political Economy, 21(5), 437-454.

https://doi.org/10.1080/13563467.2015.1134465

Wei, H., Gao, K., \& Wang, W. (2019). Understanding the relationship between grit and foreign language performance among middle school students: the roles of foreign language enjoyment and classroom environment. Frontiers in Psychology, 10, 1508. https://doi:10.3389/fpsyg.2019.01508

Yamashita, T. (2018). Grit and second language acquisition: Can passion and perseverance predict performance in Japanese language learning? [Unpublished MA thesis]. University of Massachusetts.

Zeng, G., Chen, X., Cheung, H. Y., \& Peng, K. (2019). Teachers' growth mindset and work engagement in the Chinese educational context: Well-being and perseverance of effort as mediators. Frontiers in Psychology, 10, 839. https://doi:10.3389/fpsyg.2019.00839

Zhao, J., \& Wang, M. (2014). Mothers' academic involvement and children's achievement: Children's theory of intelligence as a mediator. Learning and Individual Differences, 35, 130-136. https://doi.org/10.1016/j.lindif.2014.06.006

\section{APPENDIX}

\section{Interview questions}

1. Did you make any changes in your effort in teaching English in this session of online classroom (preparing teaching materials, language tasks, managing the class, doing extra activities, etc.) while facing failure or the possibility of failure in your teaching? Please explain. What caused this change?

2. To what extent do you see this change of effort noticeable compared to the previous sessions of the course?

3. Were there any changes in your interest in this session of the online classroom (preparing teaching materials, language tasks, managing the class, doing extra activities, etc.) while facing failure or the possibility of failure in your teaching? Please explain. What caused this change?

4. To what extent do you see this change of interest noticeable compared to the previous sessions of the course? 
Table S1. Explanations of the Teacher's Grit throughout the course

\begin{tabular}{|c|c|c|c|c|c|c|}
\hline Session & Time & Activity & Effort & Interest & Causes & Pressure \\
\hline \multirow[t]{2}{*}{$\begin{array}{l}1^{\text {st }} \text { session } \\
4 \text { August }\end{array}$} & First half & $\begin{array}{l}\text { Asking questions as review and warm- } \\
\text { up }\end{array}$ & Low & Low & $\begin{array}{l}\text { (1) Improvising (no need for focused efforts) } \\
\text { (2) No new content was to be instructed, and the aim was only a review }\end{array}$ & No \\
\hline & Second half & $\begin{array}{l}\text { The students' doing an in-class } \\
\text { exercise regarding time expression } \\
\text { with the present continuous tense }\end{array}$ & High & Low & $\begin{array}{l}\text { (1) Students' sense of confusion } \\
\text { (2) Under time pressure due to losing control of the class } \\
\text { (3) Exam in the next week } \\
\text { (4) Scores being monitored by the supervision team, being misjudged for her teaching performance } \\
\text { (5) Losing interest in teaching online }\end{array}$ & Yes \\
\hline $\begin{array}{l}2^{\text {nd }} \text { session } \\
6 \text { August }\end{array}$ & First half & $\begin{array}{l}\text { Checking students' homework } \\
\text { (question formation) }\end{array}$ & Low & Low & $\begin{array}{l}\text { (1) Familiar subjects for students } \\
\text { (2) Passive role of teacher due to students' involvement in performing the task } \\
\text { (3) No challenge was involved }\end{array}$ & No \\
\hline & Second half & $\begin{array}{l}\text { Teaching new grammar (present } \\
\text { continuous with a focus on possessive } \\
\text { and objective pronouns) followed by } \\
\text { reading section }\end{array}$ & Low & High & $\begin{array}{l}\text { (1) Students' sense of confusion about making sentences with objective pronouns } \\
\text { (2) Being under time pressure to follow the lesson plan } \\
\text { (3) The possibility of her being evaluated as weak in teaching and losing her face before the supervision } \\
\text { team } \\
\text { (4) Her being keen on the topic despite the possibility of her failure }\end{array}$ & Yes \\
\hline \multirow[t]{2}{*}{9 August } & First half & $\begin{array}{l}\text { Checking homework related to the } \\
\text { reading of the previous session }\end{array}$ & Low & High & $\begin{array}{l}\text { (1) Easy and evident to students that left her with almost no effort to explain anything } \\
\text { (2) The fact that students received feedback from each other and most of the mistakes were corrected by } \\
\text { peer correction pleased her }\end{array}$ & No \\
\hline & Second half & $\begin{array}{l}\text { Story-telling, conducted in two parts: } \\
\text { reading out loud and summarizing }\end{array}$ & Low & High & $\begin{array}{l}\text { (1) Most of the students' pronunciation and grammatical mistakes were corrected by peer-correction } \\
\text { (2) The excellent control of class was viewed by the supervision team }\end{array}$ & No \\
\hline \multirow[t]{2}{*}{$\begin{array}{l}4^{\text {th }} \text { session } \\
11 \text { August }\end{array}$} & First half & $\begin{array}{l}\text { Doing a warm-up activity related to the } \\
\text { reading passage of that unit }\end{array}$ & Low & Low & $\begin{array}{l}\text { (1) No special effort } \\
\text { (2) Showed some slides and asked some questions }\end{array}$ & No \\
\hline & Second half & $\begin{array}{l}\text { Teaching the reading passage about } \\
\text { two flooded cities }\end{array}$ & High & Low & $\begin{array}{l}\text { (1) Lots of new, unfamiliar vocabulary } \\
\text { (2) Long reading passage was a little difficult and boringfor students } \\
\text { (3) Predictable problems occurred }\end{array}$ & No \\
\hline $\begin{array}{l}5^{\text {th }} \text { session } \\
13 \text { August }\end{array}$ & First half & $\begin{array}{l}\text { teaching the vocabulary (about means } \\
\text { of transportation) followed by teaching } \\
\text { reading passage (about different ways } \\
\text { of going to school) by snapshot } \\
\text { listening }\end{array}$ & Low & Low & $\begin{array}{l}\text { (1) Means of transportation were simple and evident; no ambiguity raised; not much time or effort taken } \\
\text { (2) Sense of confusion among students because reading passage required knowledge of geography as } \\
\text { expected. She dealt with it. }\end{array}$ & No \\
\hline
\end{tabular}




\begin{tabular}{|c|c|c|c|c|c|c|}
\hline & Second half & Taking grammar quiz & High & High & $\begin{array}{l}\text { (1) Exam regarding the grammatical structures learnt during initial sessions. } \\
\text { (2) Under pressure for designing and taking the online quiz for the first time. } \\
\text { (3) Stressed out that students' performance in the online quiz might lead to her failure in her profession. } \\
\text { (4) Under pressure as performance on the quiz was being monitored by the supervision team. }\end{array}$ & Yes \\
\hline $\begin{array}{l}6^{\text {th }} \text { session } \\
16 \text { August }\end{array}$ & First half & $\begin{array}{l}\text { Review of students' homework (to } \\
\text { read the stories they had made with } \\
\text { new words from the previous session) }\end{array}$ & Low & Low & (1) Students satisfactorily answered the questions using peer correction. & No \\
\hline & Second half & $\begin{array}{l}\text { Teaching the new vocabulary (about } \\
\text { electronic devices) }\end{array}$ & Low & High & $\begin{array}{l}\text { (1) Students' showed interest in the task. } \\
\text { (2) Students relating the task to their personal experience with electronic devices created a joyful } \\
\text { atmosphere. } \\
\text { (3) Students' joyous efforts. } \\
\text { (4) Students actively participated in the class. } \\
\text { (5) Good control over the class. }\end{array}$ & No \\
\hline $\begin{array}{l}7^{\text {th }} \text { session } \\
18 \text { August }\end{array}$ & First half & $\begin{array}{l}\text { A review of students' assignments (to } \\
\text { describe a number of jobs) }\end{array}$ & Low & Low & $\begin{array}{l}\text { (1) The students did their job satisfactorily } \\
\text { (2) No unexpected problem showed up }\end{array}$ & No \\
\hline & Second half & $\begin{array}{l}\text { The new vocabulary lesson about jobs. } \\
\text { Students then create stories about } \\
\text { different jobs and occupations using } \\
\text { do/does }\end{array}$ & Low & Low & $\begin{array}{l}\text { (1) Making similar mistakes as before in using do/does } \\
\text { (2) Used peer-correction to correct students. } \\
\text { (3) Not interesting to her due to witnessing similar mistakes from students after trying so hard to teach } \\
\text { the correct form. }\end{array}$ & No \\
\hline $\begin{array}{l}8^{\text {th }} \text { session } \\
20 \text { August }\end{array}$ & First half & $\begin{array}{l}\text { Check students' homework from the } \\
\text { previous session }\end{array}$ & Low & High & $\begin{array}{l}\text { (1) Students' performance was satisfactory because her last session's method regarding using peer- } \\
\text { correction to solve students' grammar problems worked. }\end{array}$ & No \\
\hline \multirow{3}{*}{$\begin{array}{l}9^{\text {th }} \text { session } \\
23 \text { August }\end{array}$} & Second half & $\begin{array}{l}\text { A reading passage about "unusual } \\
\text { ways to go to school" }\end{array}$ & High & High & $\begin{array}{l}\text { (1) Challenging topic for students. } \\
\text { (2) Her explanations were not sufficient for her students' understanding. }\end{array}$ & Yes \\
\hline & First half & $\begin{array}{l}\text { Checking homework and assignments } \\
\text { of previous session }\end{array}$ & Low & Low & $\begin{array}{l}\text { (1) Some questions/answers acitiviteswere done to check the understanding of the extra reading } \\
\text { questions. }\end{array}$ & No \\
\hline & Second half & $\begin{array}{l}\text { Teaching grammar (difference between } \\
\text { simple and continuous present) along } \\
\text { with Activities related to grammar } \\
\text { section }\end{array}$ & Low & Low & $\begin{array}{l}\text { (1) Students' conundrum in understanding the grammar point. } \\
\text { (2) Her sense of failure in making them understand the subject matter. } \\
\text { (3) Frustrated, stressed. }\end{array}$ & Yes \\
\hline
\end{tabular}

Note. The bold parts refer to changes in effort and interest under pressure, characterizing grit changes. 